\title{
Optimal timing of rest perfusion with regadenoson stress testing - normal volunteer study of quantitative MRI perfusion
}

\author{
Sujethra Vasu*, W Patricia Bandettini, Li-Yueh Hsu, Peter Kellman, Joel Wilson, Steve Leung, Sujata M Shanbhag, \\ O Julian Booker, Christine Mancini, Jennifer Henry, Tracy Lowrey, Andrew E Arai
}

From 2011 SCMR/Euro CMR Joint Scientific Sessions

Nice, France. 3-6 February 2011

\section{Introduction}

Many MRI perfusion protocols perform rest imaging a few minutes after stress imaging. Regadenoson is a new, selective Adenosine-2A receptor agonist used for myocardial perfusion imaging. The purpose of this study was to assess how well rest perfusion imaging 20 minutes after regadenoson stress reflects true baseline rest perfusion.

\section{Hypothesis}

"Rest perfusion" performed 20 minutes after regadenoson stress and reversal with aminophylline is higher than rest perfusion before administration of regadenoson.

\section{Methods}

Seventeen healthy normal volunteers with Framingham score less than $1 \%$ underwent vasodilator stress testing with regadenoson using a SSFP sequence. Rest imaging (Rest 1) was performed initially. Twenty minutes later, regadenoson $400 \mathrm{mcg}$ was administered as a 10 second injection with saline flush. Stress imaging was done 70 seconds after the injection. All volunteers received aminophylline $100 \mathrm{mg}$. A second rest perfusion (Rest 2) imaging was done 20 minutes later. Myocardial blood flow (MBF) in $\mathrm{ml} / \mathrm{min} / \mathrm{g}$ and myocardial perfusion reserve (MPR) were quantified using a fully quantitative model constrained deconvolution (MCD).

\section{Results}

Rest $2 \mathrm{MBF}$ (mean \pm standard error) done 20 minutes after regadenoson stress was $1.43 \pm 0.10$, higher than

National Institutes of Health, Bethesda, MD, USA rest perfusion done before regadenoson administration (Rest 1 ) is $1.18 \pm 0.07, \mathrm{p}=.009$. The stress MBF is 3.72 \pm 0.18 . Using the rest perfusion after regadenoson as true resting perfusion, leads to a $15 \%$ underestimation of MPR ( $2.75 \pm 0.21$ Stress/Rest 2 vs. $3.33 \pm 0.22$ Stress/ Rest $1, \mathrm{p}=0.005)$. Figures 1 and 2 .

\section{Conclusions}

Rest perfusion done 20 minutes after regadenoson 400 mcg has not returned to baseline resting myocardial
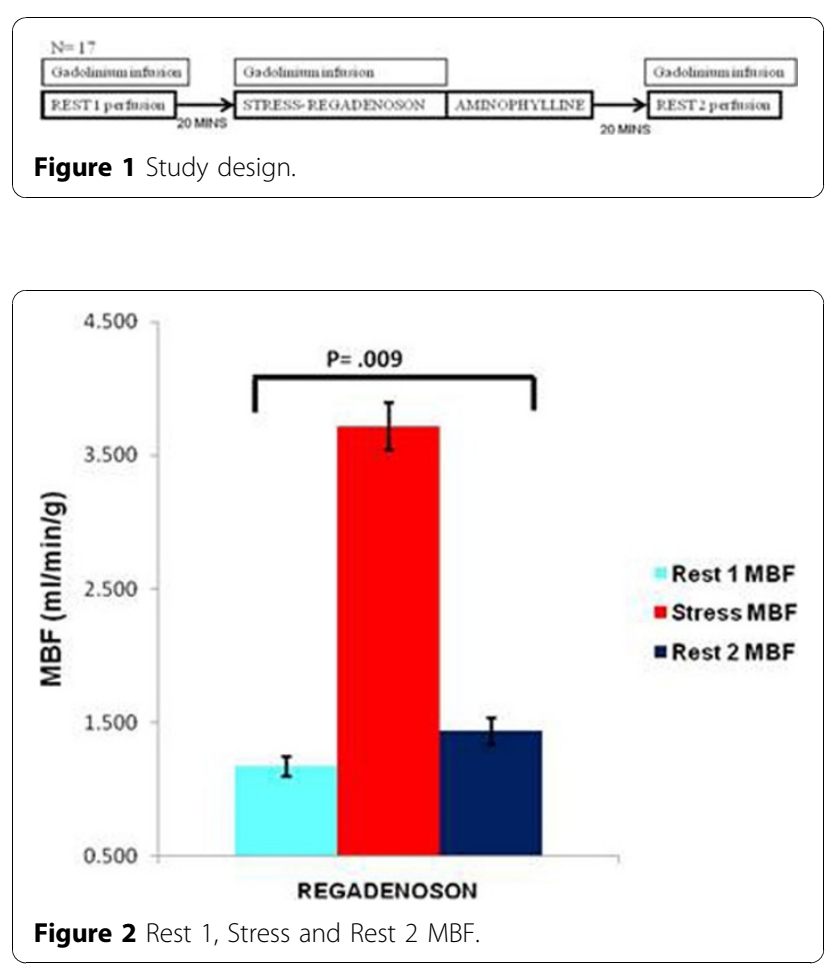

(c) 2011 Vasu et al; licensee BioMed Central Ltd. This is an open access article distributed under the terms of the Creative Commons 


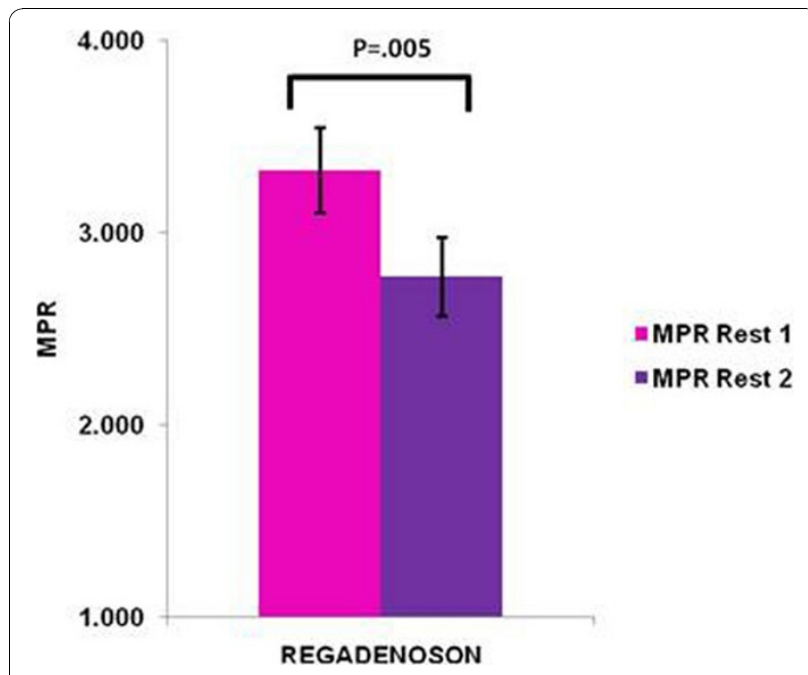

Figure 3 Comparison between MPR based on Rest 1 and Rest 2 MBF.

perfusion despite reversal with 100mg of aminophylline. This leads to underestimation of MPR. Regadenoson has a longer duration of effect which might be less suitable for rest perfusion done 20 minutes after stress.

Published: 2 February 2011

doi:10.1186/1532-429X-13-S1-P128

Cite this article as: Vasu et al:: Optimal timing of rest perfusion with regadenoson stress testing - normal volunteer study of quantitative MRI perfusion. Journal of Cardiovascular Magnetic Resonance 2011 13(Suppl 1): P128.
Submit your next manuscript to BioMed Central and take full advantage of:

- Convenient online submission

- Thorough peer review

- No space constraints or color figure charges

- Immediate publication on acceptance

- Inclusion in PubMed, CAS, Scopus and Google Scholar

- Research which is freely available for redistribution

Submit your manuscript at www.biomedcentral.com/submit
C Biomed Central 